\title{
Implementation of a Data-Driven Hospitality Lexis Learning Programme
}

\author{
PIYAPONG LAOSRIRATTANACHAI \\ English for Service Industry Programme, \\ Faculty of Liberal Arts and Science \\ Kasetsart University, Thailand \\ piyapong.l@ku.th \\ SUGUNYA RUANGJAROON \\ Linguistics Programme, \\ Faculty of Humanities \\ Srinakharinwirot University, Thailand
}

\begin{abstract}
Data-driven learning has been recognized a potential tool for enhancing learning outcomes. The current study designed a data-driven hospitality lexis learning programme to facilitate the learning of hospitality vocabulary by autonomous learners. To achieve the objectives, the development of learners' hospitality vocabulary knowledge was measured using the T-test based on pre-testing and post-testing. In addition, the learners' opinions were explored using two types of questionnaire: the Mentimeter online programme and an open-ended questionnaire. The results of the T-test scores confirmed that the hospitality vocabulary knowledge of learners was improved after learning autonomously using the data-driven hospitality lexis learning programme. The results from the questionnaire indicated that most of the learners thought that the program was convenient, useful, and easily understood. Learners considered that using the programme helped them to be more responsible, to be better at time management, and to expand their vocabulary regarding hospitality. Therefore, using the online programme would be suitable as a recommended alternative to facilitate learning vocabulary for autonomous learners. Thus, such online programmes should be promoted and created in both general and specific fields of learning vocabulary. These findings could be extended to other English-for-specific-purposes contexts to assist learners in dealing with terminology in their fields.
\end{abstract}

Keywords: data-driven learning; learning web media; autonomous learner; hospitality business lexis; vocabulary learning

\section{INTRODUCTION}

Hospitality, comprising tourism, accommodation, and the airline industry, is one of the major business sectors and generates enormous income for the economy in Thailand. In 2017, Thailand was ranked fifth highest of countries based on the value of hospitality service exports (Bank of Thailand, 2017). The National Statistical Office (2013) indicated that 1755844 citizens were working in hospitality businesses. This led to popularity in studying in relevant hospitality business programmes in Thailand, with approximately 260 of these programmes supporting students' needs (Office of the Higher Education Commission, 2018). Therefore, more and more graduates are entering hospitality businesses; however, their potential to survive the work life is doubtful; for example, they lack qualified language skills. To enter the hospitality workforce, one should have knowledge and skills in work operations, service mind, and be reasonably fluent in at least one foreign language, with English being the most predominant language used worldwide. A non-native English speaker requires mastery of English language skills, comprising listening, speaking, reading, writing, vocabulary, and grammar, to be able to communicate effectively. Among English language skills, vocabulary plays an important role as the foundation of language and has a large effect on communication; for example, a non-native speaker who uses correct grammar with incorrect vocabulary would not be understood properly, whilst a speaker using appropriate vocabulary with poor grammar would be understood much better (Laufer \& Nation, 1995; Widdowson, 1978). People from 
different countries can communicate when they possess adequate English vocabulary knowledge (Nguyen \& Nation, 2011). Penha (2006) as cited in Kaya (2014) concordantly stated that English listening, speaking, reading, and writing cannot be taught without adequate vocabulary knowledge. Lestari and Hardiyanti (2020) proposed that vocabulary mastery was essential for effective communication. Apart from communication, vocabulary knowledge is significant in academic achievement since it is associated with knowledge acquisition (Laufer, 2005; Nation, 1990; Schmitt, 2008). Zahar et al. (2001) claimed that spending an hour reading might provide the opportunity for a learner to encounter about two new words. Hence, teaching and learning vocabulary methods should be applied to facilitate and accelerate learning vocabulary.

One teaching and learning vocabulary method applies data-driven learning (DDL). In DDL, a large corpus is provided containing texts relevant to the learners' needs (Boulton, 2017). Teachers use extracted texts, tools, and corpus linguistics approaches in combination for pedagogical purposes (Flowerdew, 2005; Gilquin \& Granger, 2010). Learning and teaching vocabulary through DDL empowers learners to observe authentic language use and prepares learners for encounters with real-life situations. In addition, once familiar with authentic language use, learners can then draw their own conclusions and this transforms subordinate and passive learners into autonomous and active ones (Ädel, 2010; Bernardini, 2000; Boulton, 2011; Gavioli, 2009; Huang, 2011; Johns, 1986, 1991; Reppen, 2010; Soruç \& Tekin, 2017). According to Boulton (2017), empirical DDL studies have mostly focused on university students, perhaps because the university level is where this method is most beneficial and properly applied. Often, the university level is when learners start more extensively learning English for specific purposes. Thus, applying DDL in teaching and learning vocabulary for university students could be most useful. Nevertheless, teaching vocabulary to students in classes is often ineffective since the time available in each class is restricted. Therefore, to facilitate students developing adequate vocabulary skills, autonomous learning material integrated with DDL should be provided.

In contrast to conventional pedagogy that lecture-based teaching is the most common form of teaching, teachers are now required to be proficient in both conventional and online teaching approaches (Arifani et al., 2020). The advance of information technology in the $21^{\text {st }}$ century was the main factor that pushed society into encountering new challenges and opportunities (Khan, 2012; Pacansky-Brock, 2013), and into developing education in the modern era. Communication technology has been applied systematically into the education system, corresponding with the speed of information perception by learners. As a result, teaching integrated with online media was proposed for autonomous learners (Anastasiya \& Vira, 2018; Shelly et al., 2007). It is agreed that integration between autonomous learning material and internet technology is one of the best ways to promote learning (McInnis, 2002; Norazah et al., 2005). Islam et al. (2015) further stated that e-learning for higher learning in institutions has steadily increased its significant role in teaching and learning languages. Omar et al. (2018) confirmed that e-learning plays a crucial role in teaching and learning since it is beneficial to both teachers and learners and improves on the conventional approach by making it more complete.

Since learning in class alone might be insufficient for learners, the authors proposed the notion of using DDL and corpora as supplementary learning material to reinforce vocabulary knowledge. To increase the effectiveness of teaching and learning, a blended learning approach should use both traditional and online teaching approaches. The blended learning approach implementation is accepted extensively, and it turns out to be beneficial to learning and teaching language (Arifani et al., 2020). Hence, the current study aimed to use DDL to facilitate learning vocabulary via an online learning programme. The hospitality word lists and authentic language data from corpora compiled by Laosrirattanachai and Ruangjaroon (2021) were used 
to design an online learning programme. The lessons and exercises provided in the online lessons were generated based on Schmitt's vocabulary learning strategies (1997). Furthermore, the generated online learning programme was provided to learners to determine whether the programme facilitated learners in developing their hospitality vocabulary. The results should encourage learners to use the online programme to improve their vocabulary knowledge.

The current paper is organized as follows. In the Theoretical Background section, the notion of DDL is introduced. Schmitt's vocabulary learning strategies (1997) and the tendency of online learning media for education in the $21^{\text {st }}$ century are also considered. The Methodology section details the procedures regarding how the research is conducted, participant selection, and research instruments creation. The Findings section provides a comparison of the average pre-test and post-test scores of learners after using the data-driven hospitality lexis learning programme. Learners' opinions towards the programme are also included in this section. We summarise and discuss the findings and propose some recommendation in the Discussion section.

\section{RESEARCH QUESTIONS}

According to Johns (1991), DDL was an effective means for learning English by providing learners with an authentic language. As a result, learners could explore the use of vocabulary in a real situation (Johns, 1994; MaCarten, 2007). The current study attempts to investigate the development of learners' vocabulary knowledge after using the data-driven hospitality lexis learning programme based on generated word lists and a corpus and also considers their opinions towards the online programme. Therefore, the following research questions are addressed:

1. Does the data-driven hospitality lexis learning programme contribute to learner's vocabulary knowledge?

2. What are the learner's opinions towards the data-driven hospitality lexis learning programme?

\section{THEORETICAL BACKGROUND}

\section{LEARNING AND TEACHING VOCABULARY THROUGH A DATA-DRIVEN LESSON}

The conventional teaching approach employed spoon feeding provided by teachers. John (1994) attempted to decrease the role of the middle person - of course referring to the teacher, by proposing to apply data-driven learning (DDL). DDL was first mentioned by Johns (1991). It was defined as an approach to learning a language that was driven using linguistic data. DDL was considered an efficient means for teaching English as a foreign or second language since learners could learn from an authentic language in a corpus; for example, learners could investigate how vocabulary is used in context (Johns, 1994; MaCarten, 2007). In current years, DDL has been applied in three main ways (Boulton, 2017). First, DDL-like practice is provided to the web as corpus. Second, the concordance lines extracted from the corpus help integrate DDL into learning and teaching language. Third, teaching academic writing uses language patterns in corpora as a reference resource. In language learning, DDL facilitates learners to explore polysemy, semantic prosody, phraseology, and pattern grammar. In teaching, DDL supports teachers by serving as a useful source for teaching reading and writing. It also helps teachers to develop corpus-based lessons and exercises (Conrad, 2000; Kilıçkaya, 2015; 
Kırkgöz, 2006; Reppen, 2010). Therefore, DDL is now widely used and was recently described as "new," "innovative," "fresh," and "interesting" (Lin \& Lee, 2015).

Compared to the conventional approach, DDL is successful in advocating learning experience and providing learners with greater opportunity to exercise the skill of language discovery (Allan, 2009; Altenberg \& Granger, 2002; Bondi, 2001). A number of scholars have affirmed the use of DDL to promote language knowledge development by learners. DDL equips learners with knowledge that might not be provided by a textbook (Römer, 2011). Furthermore, it has been used to promote learners' productive skills such as writing (Cotos, 2014; Huang, 2014; Yoon \& Hirvela, 2004) and speaking (Geluso \& Yamaguchi, 2014). Apart from writing and speaking skills, DDL has been used to promote other aspects of language learning such as meaning distinction (MacArthur \& Littlemore, 2008) and lexicogrammar (Liu $\&$ Jiang, 2009). As a result, learners could self-regulate their own profiles of language meaning and uses. By being allowed to self-regulate and make decisions, they then developed their vocabulary knowledge independently and responsibly (Dörnyei \& Skehan, 2003; Soruç \& Tekin, 2017).

When discussing learning vocabulary meaning, it might be easy just to look up the meaning of the words in a dictionary, in both the printed media or online, but that does not make learners memorise and use words properly. Many scholars supported the idea of applying DDL instead of using a dictionary. They claimed that learners remembered more words through learning vocabulary using DDL rather than engaging in online dictionary use (Çelik, 2011). Of course, dictionary use effectively helped learners to know the exact and correct meaning of the word, but DDL could develop learners' understanding and use of words on a syntactic level (Frankenberg-Garcia, 2012).

Even though using a corpus to facilitate learning might somehow be complicated and somewhat difficult (Tono, 2003; Umesaki, 2004; Yoon \& Hirvela, 2004), scholars still insisted that learners explicitly admired the application of data-driven vocabulary learning (Kilimci, 2017; Smith, 2020). To demonstrate the benefits of DDL in vocabulary learning in the present study, the authors aimed to create online data-driven lessons by utilising language data from the compiled corpora comprising the Tourism Business Corpus, Hotel Business Corpus, and Airline Business Corpus and to ease the difficulty of learning through DDL by designing lessons based on the vocabulary learning strategies of Schmitt (1997).

\section{VOCABULARY LEARNING STRATEGIES AND ASSESSING VOCABULARY}

In 1990, Oxford proposed taxonomy of learning strategies referring to the approaches used by learners to facilitate the learning of language by making the approach more comfortable and easier. Afterwards, Schmitt (1997) adapted this concept and proposed a taxonomy of 58 vocabulary learning strategies (VLSs). Catalán (2003) claimed that a VLS refers to the procedures of exploring the meaning of new words, word-meaning retention, recalling the memorised words, and producing language using the memorized words applied by learners. Schmitt (1997) divided the VLS into two main categories consisting of discovery strategies and consolidation strategies. Discovery strategies were defined as the methods of exploring new words which were further sub-categorised as determination strategies (DETs), and social strategies (SOCs). The consolidation strategies accounted for retaining words once they were discovered which were sub-categorised as social strategies (SOCs), memory strategies (MEMs), cognitive strategies (COGs), and metacognitive strategies (METs). DETs involve learning vocabulary individually without assistance. On the other hand, SOCs involve learning vocabulary by engaging with people. MEMs refer to learning vocabulary by connecting words with pre-existing knowledge. COGs focus on using repetition and mechanical means such as word lists, notebooks, or electronic devices to learn vocabulary. METs consider the appropriate 
method that best suits learning vocabulary by making decisions about planning, monitoring, or assessing the methods. In several studies, the VLS approach was used as a framework to explore what VLSs were mostly used by learners (Baskin et al., 2017; Puagsang \& Intharaksa, 2017; Vo \& Jaturapitakkul, 2016). Some scholars analysed the relationship between the VLS used by learners and the vocabulary size possessed by learners (Chumworatayee \& Pitakpong, 2017; Teng, 2015). The taxonomy of 58 VLSs is provided in Table 1.

TABLE 1. Taxonomy of 58 vocabulary learning strategies

\begin{tabular}{|c|c|c|}
\hline Category (2) & Sub-category (6) & Strategy (58) \\
\hline \multirow[t]{2}{*}{$\begin{array}{l}\text { Discovery } \\
\text { strategies (2) }\end{array}$} & $\begin{array}{l}\text { Determination } \\
\text { strategies (9) }\end{array}$ & $\begin{array}{l}\text { 1) analyse part of speech, 2) analyse affixes and roots, 3) check for L1 cognate, 4) analyse } \\
\text { any available pictures or gestures, 5) guess from textual context, 6) bilingual dictionary, 7) } \\
\text { monolingual dictionary, 8) word lists, 9) flash cards }\end{array}$ \\
\hline & $\begin{array}{l}\text { Social strategies } \\
\text { (5) }\end{array}$ & $\begin{array}{l}\text { 1) ask teacher for an LI translation, 2) ask teacher for paraphrase or synonym of new word, } \\
\text { 3) ask teacher for a sentence including the new word, 4) ask classmates for meaning, 5) } \\
\text { discover new meaning through group work activity }\end{array}$ \\
\hline \multirow[t]{4}{*}{$\begin{array}{l}\text { Consolidation } \\
\text { strategies (4) }\end{array}$} & $\begin{array}{l}\text { Social strategies } \\
\text { (3) }\end{array}$ & $\begin{array}{l}\text { 1) study and practise meaning in a group, 2) teacher checks students' flash cards or word lists } \\
\text { for accuracy, 3) interact with native speakers }\end{array}$ \\
\hline & $\begin{array}{l}\text { Memory } \\
\text { strategies (27) }\end{array}$ & $\begin{array}{l}\text { 1) study word with a pictorial representation of its meaning, 2) image word's meaning, } 3 \text { ) } \\
\text { connect word to a personal experience, 4) associate the word with its coordinates, 5) connect } \\
\text { the word to its synonyms and antonyms, 6) use semantic maps, 7) use 'scales' for gradable } \\
\text { adjectives, 8) Peg Method, 9) Loci Method, 10) group words together to study them, 11) } \\
\text { group words together spatially on a page, 12) use new words in sentences, 13) group words } \\
\text { together within a storyline, 14) study the spelling of a word, 15) study the sound of a word, } \\
\text { 16) say new word aloud when studying, 17) image word form, 18) underline initial letter of } \\
\text { the word, 19) configuration, 20) use Keyword Method, 21) affixes and roots (remembering), } \\
\text { 22) part of speech (remembering), 23) paraphrase the word's meaning, 24) use cognates in } \\
\text { study, 25) learn the words of an idiom together, 26) use physical action when learning a word, } \\
\text { 27) use semantic feature grids }\end{array}$ \\
\hline & $\begin{array}{l}\text { Cognitive } \\
\text { strategies (9) }\end{array}$ & $\begin{array}{l}\text { 1) verbal repetition, 2) written repetition, 3) word lists, 4) flash cards, 5) take notes in class, } \\
\text { 6) use the vocabulary section in one's textbook, 7) listen to tape of word lists, 8) put English } \\
\text { labels on physical objects, 9) keep a vocabulary notebook }\end{array}$ \\
\hline & $\begin{array}{l}\text { Metacognitive } \\
\text { strategies (5) }\end{array}$ & $\begin{array}{l}\text { 1) use English-language media (songs, movies, newscasts, etc.), 2) testing oneself with word } \\
\text { tests, 3) use spaced word practice, 4) skip or pass new word, 5) continue to study word over } \\
\text { time }\end{array}$ \\
\hline
\end{tabular}

Apart from the VLS, how we assess learners' vocabulary knowledge is an important task to evaluate whether learning vocabulary is accomplished. To test learners' vocabulary knowledge, some discrete vocabulary items were recommended to be assessed (Schmitt, 2008); for example, recalling word meaning, word meaning recognition, spelling, inflectional morphology, derivational morphology, collocation, word meaning association, and formulaic language.

To promote the vocabulary learning outcomes, the current study applied the VLS (Schmitt, 1997) to generate the data-driven hospitality lexis learning programme. In addition, the vocabulary assessment items (Schmitt, 2008) were used to create tests and exercises in the data-driven hospitality lexis learning programme.

\section{ONLINE LEARNING MEDIA FOR THE EDUCATION IN THE $21^{\text {ST }}$ CENTURY}

Any created lessons might somehow contribute to learners' vocabulary knowledge improvement. However, when it comes to an autonomous learner, learning through a plain book might be a problem since it is difficult to maintain the learners' interest. The authors then proposed a data-driven lesson in an online programme. The integration of learning, internet, and information technology leads to the incremental development of learning outcomes and also prepares learners to be ready for the digital age (Hajhashemi et al., 2014; McInnis, 2002; Norazah et al., 2005; Pacansky-Brock, 2013) because the integration gives learners a chance to participate in the learning process, and an opportunity to give feedback to teachers. 
Furthermore, it generates a virtual community containing learners, teachers, programmers, parents, and any interested people outside the classroom (Bill \& Gates, 2010; Bransford et al., 1999; Goldman, 2011; Henry et al., 2005; McCoog, 2007). One of the factors supporting autonomous learning through an online programme is that 85.9 percent of citizens aged between 15 and 24 years have experienced learning, access, and use the internet and information technology in their daily life (National Statistical Office, 2016). The internet is important not only in daily life, but also in the education system (Lego Muñoz \& Towner, 2009; Petrovic et al., 2012). Several studies confirmed that applying the internet and information technology with learning can boost the learning outcome. Nonetheless, there has been little implementation in classes (Chen \& Bryer, 2012). The lack of implementation might have arisen from many obstacles, such as institutes providing inadequate budgets for creating online lessons, and online learning materials might not be user-friendly enough for teachers. This would force teachers to spend most of the time in the class teaching learners how to use the learning programme, not the knowledge provided in the programme. Some institutes avoid using self-generated, poor quality, online learning programmes by choosing to use free online programmes provided by famous institutes but end up finding that the provided learning programmes do not harmonise with individual courses (Fung, 1999; Fung \& Pun, 2001; Kong, $\mathrm{Au}, \&$ Pun, 1999; Law et al, 1999).

There are many advantages from using an online autonomous vocabulary learning programme, as learners can access the lessons anywhere and at any time, ensuring equality among learners, while the online lessons are more interesting and attractive than learning via paper books in the old-fashioned learning style. In addition, learners can self-evaluate immediately after they finish an online lesson (Hajhashemi et al., 2014; Nelson et al., 1976). Unfortunately, there are still some disadvantages to learning through online lessons, such as internet connection and electricity supply requirement.

\section{METHODOLOGY}

To conduct the research, the authors followed the steps indicated in Figure 1. 


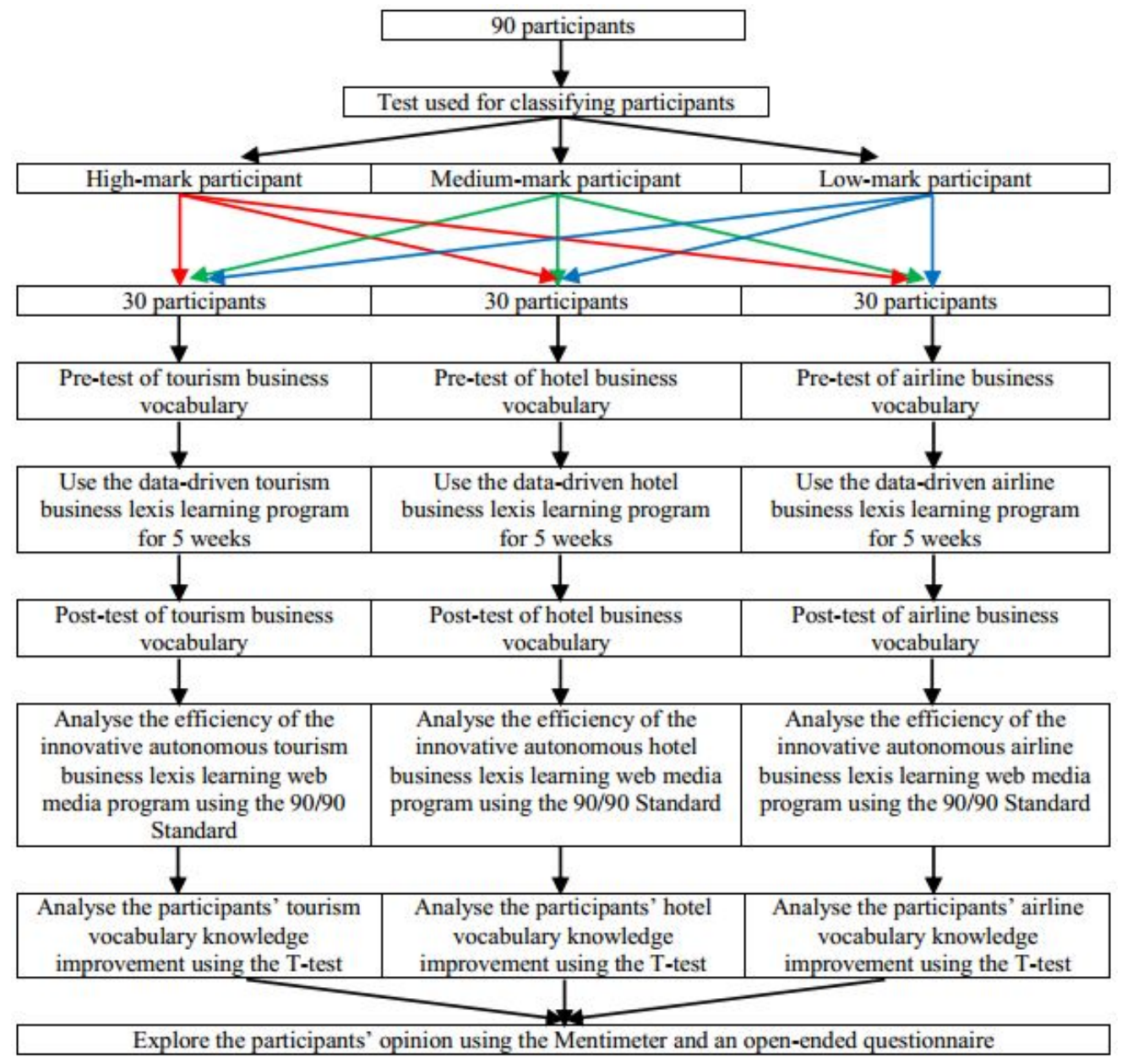

FIGURE 1. Steps for conducting the research

\section{CORPORA SELECTION}

Selecting the appropriate corpora was crucial in creating the data-driven hospitality lexis learning programme. Since the authors aimed to create a learning programme related to hospitality vocabulary, hospitality corpora were needed. The authors chose to use the Tourism Business Corpus (TBC), Hotel Business Corpus (HBC), and Airline Business Corpus (ABC) (Laosrirattanachai \& Ruangjaroon, 2021). The corpora contain collected language data from various sources comprising official websites, magazines, news, and work operation manuals related to tourism, hotel, and airline businesses.

\section{PARTICIPANTS}

The current study used one group in the pre-test and post-test design by choosing participants using the purposive sampling method. As a result, 90 first-year students studying in the English for Service Industry programme were chosen as the participants. The authors chose first-year students because all of them had passed the Ordinary National Educational Test (O-NET). The O-NET is used to test students' general and academic English that is required of grade-12 students throughout Thailand every year. It was created by National Institute of Educational Testing Service (Public Organization). Each students' vocabulary knowledge was limited compared to the second to fourth-year students who had attended many courses related to hospitality. The participants in this study were divided into three experimental groups: tourism, hotel, and airline businesses. 


\section{RESEARCH INSTRUMENTS}

There were three research instruments used in this study: an online learning programme, tests, and questionnaires. The online learning programme used in this study was the data-driven hospitality lexis learning programme. It comprised three sub-courses: tourism business, hotel business, and airline business. Each individual course had five units, and each unit had three activities. The second instrument of this study was the hospitality vocabulary tests comprising: 1) a test used to classify students into three groups, and 2) pre-tests and post-tests for the tourism group, hotel group, and airline business group. The test employed 60 short texts from the three corpora (TBC, HBC, and ABC). Each text had about 2-4 sentences and a blank was left for the participant's answer. The participants could choose the answer from choices provided in each item in the test. The Mentimeter online polling tool and an open-ended questionnaire were used to inspect the opinions of learners towards the data-driven hospitality lexis learning programme.

\section{DATA-DRIVEN HOSPITALITY LEXIS LEARNING PROGRAMME SCHEME}

Hospitality word lists of English were required to generate the data-driven hospitality lexis learning programme. The authors designed a self-study online programme by using the hospitality word lists generated from TBC, HBC, and ABC (Laosrirattanachai \& Ruangjaroon, 2021). The hospitality word lists comprised tourism, hotel, and airline businesses. The 125 words in each word list; Tourism Business Word List (TBWL), Hotel Business Word List (HBWL), and Airline Business Word List (ABWL), were then used to generate lessons and exercises using authentic language from the hospitality corpus compiled by the authors. As a result, the data-driven hospitality lexis learning programme was presented with three subcourses comprising the tourism, hotel, and airline businesses. Each sub-course had five units with three activities in each unit. Each unit contained 25 words, in total 125 words. The participants used the data-driven hospitality lexis learning programme for five weeks (Figure 2).
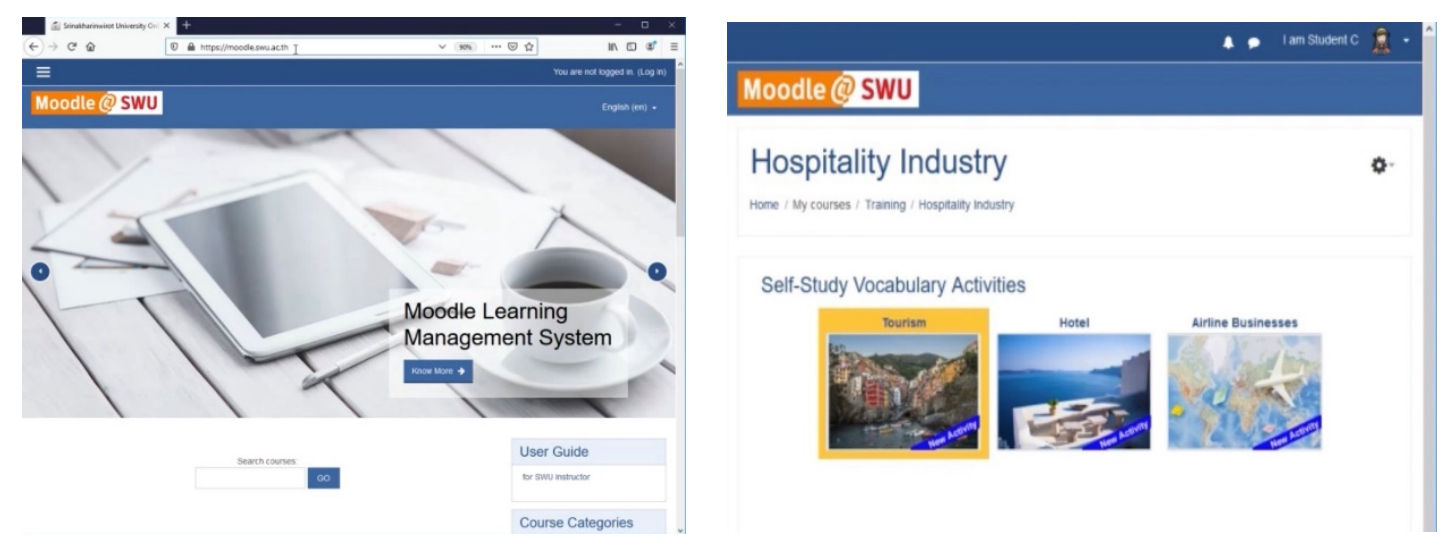

FIGURE 2. Main menu screens of data-driven hospitality lexis learning programme

The vocabulary learning strategies (Schmitt, 1997) and vocabulary assessment items (Schmitt, 2008) were integrated and used to generate lessons and exercises, since they were compatible with the desired lesson and exercise contents. Furthermore, many scholars claimed that using the 'Pictorial Vocabulary', and 'Vocabulary Cartoon' lessons was effective and beneficial for learners (Mirzaii, 2012; Tahir et al., 2020). Hence, the data-driven hospitality lexis lessons mostly used pictures and cartoons to facilitate learners to learn vocabulary through 
the programme. Due to the limitation of programme functions, 22 out of 58 taxonomies of VLS were applied in the data-driven hospitality lexis learning programme as presented in Figure 3.

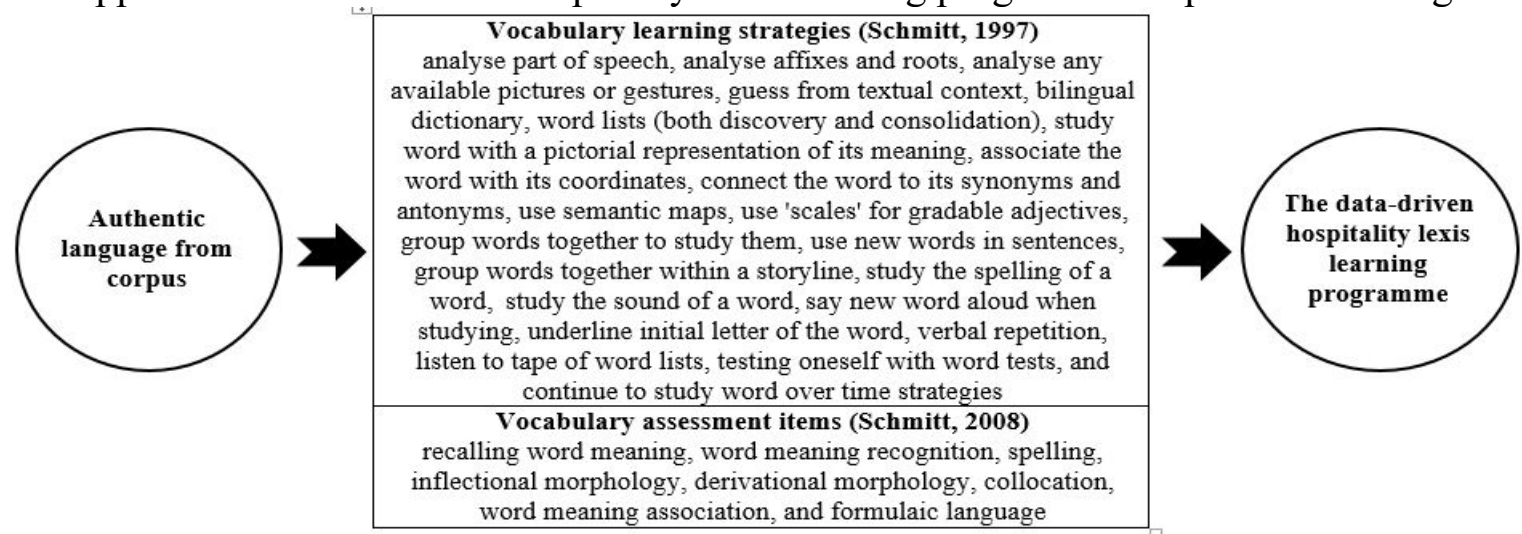

FIGURE 3. Vocabulary learning strategies (Schmitt, 1997) and vocabulary assessment items (Schmitt, 2008) used to design the programme

Some examples of lessons and exercises are presented in Figure 4.
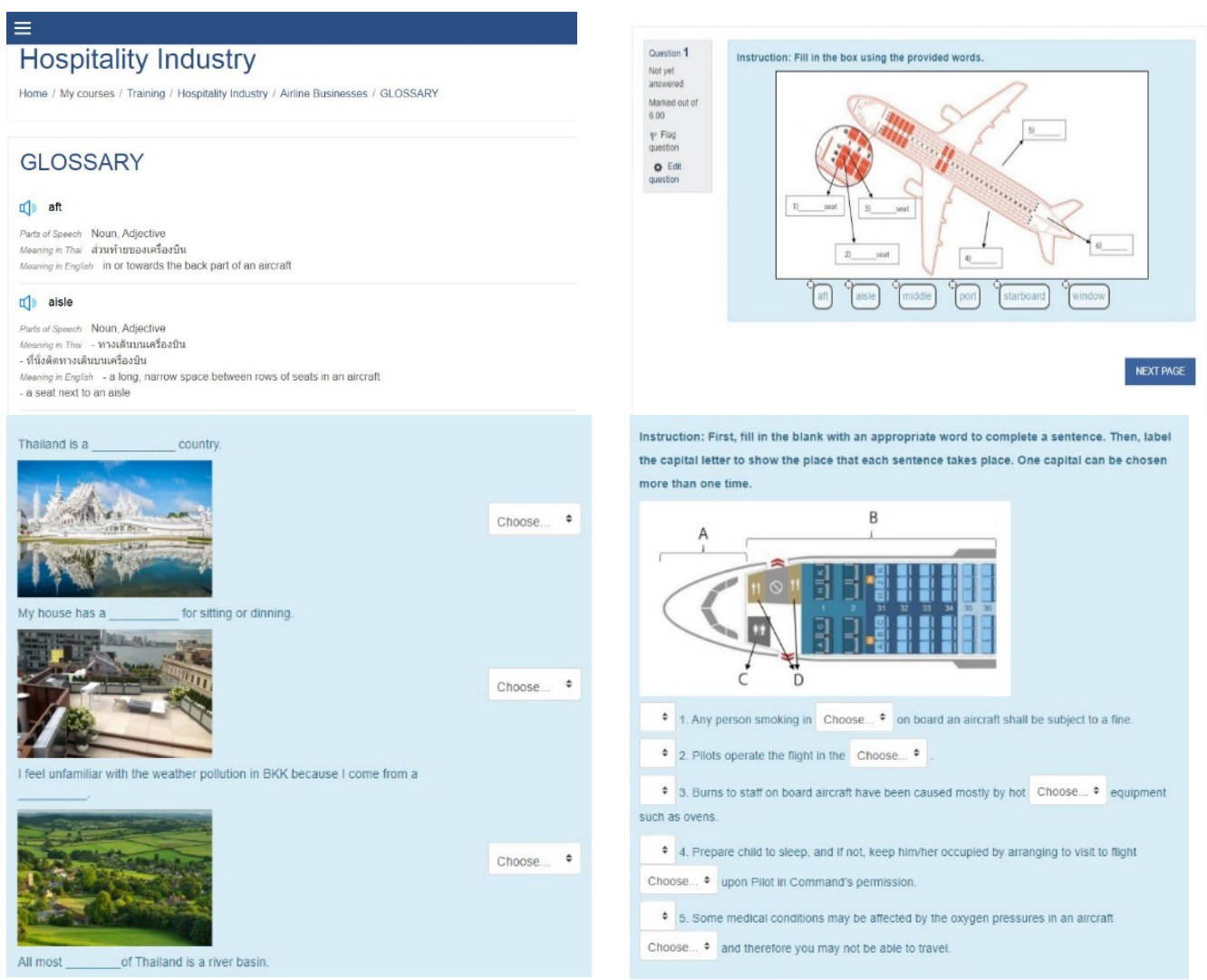

Instruction: First, fill in the blank with an appropriate word to complete a sentence. Then, label the capital lettrer to show the place that each sentence takes place. One capital can be choser more than one time.

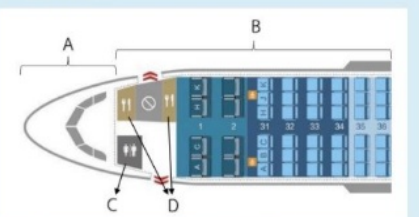

- 1.Any person smoking in choose * on board an aircran shall be subject to a fine.

- 2. Pllots operate the flight in the choose.

- 3. Burns to statt on board aircrat have been caused mostly by not choose... equipment such as ovens.

- 4. Prepare chis to sleep, and if not, keep him/ner occupiec by arranging to vish to nlight choose - upon Pllot in Command's permission.

* 5. Some medical condtions may be atrected by the oxygen pressures in an arccran Choose. : and therefore you may not be able to travel. 

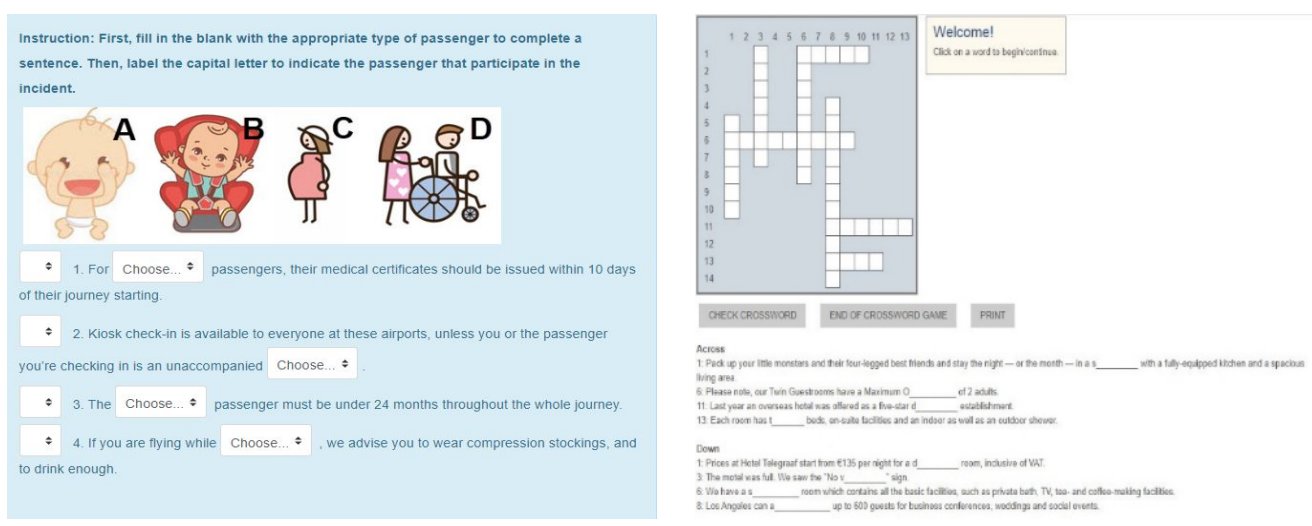

FIGURE 4. Lessons and exercises in the data-driven hospitality lexis learning programme TEST CREATION

The tests used in this study were composed of:

1) A test used to classify the participants into the three groups. The test was generated based on 20 tourism English vocabulary, 20 hotel English vocabulary, and 20 airline business English vocabulary items, a total of 60 items. The vocabulary was randomly chosen from the word lists. The purpose of this test was to grade students as having high, medium, and low hospitality vocabulary knowledge. When their ranks were identified, they were assigned to one of three different business groups. Each group contained just about the same number of participants with high, medium, and low hospitality vocabulary knowledge. Therefore, each group had 30 participants. Each group was assigned to study different hospitality business fields of vocabulary lessons including tourism, hotel, and airline business vocabulary. The participants' highest, lowest, and average scores are presented in Table 2.

TABLE 2. Participants' highest, lowest, and average scores in three groups

\begin{tabular}{cccc}
\hline Business & Max (60 pts) & Min (60 pts) & Average (60 pts) \\
\hline Tourism & 29 & 10 & 18.47 \\
Hotel & 28 & 12 & 18.97 \\
Airline & 29 & 11 & 19.33 \\
\hline
\end{tabular}

2) Pre- and post-testing of tourism business English vocabulary was used to test the tourism vocabulary knowledge of the 30 participants classified in this group. The test comprised 60 items covering 60 words which were chosen from five units. Twelve words were chosen from each unit. To decide which words were chosen, the authors chose the words listed in even numbers from each unit. The pre- and post-tests of the hotel business English vocabulary and of the airline business English vocabulary were also generated and used consistently.

All tests were generated using authentic language use from the corpora. The designs of the pre-test and post-test were similar. These multiple-choice tests were also considered by three judges who taught English professionally. The tests were then improved based on the judges' feedback.

\section{QUESTIONNAIRE CREATION}

Apart from the evaluation of the learners' vocabulary knowledge enhancement from using the programme, the opinion of the learners towards the programme was also crucial since it affected their willingness to use the programme. The participants' opinions were sought at the end of the course. The authors generated two kinds of inspection; 1) the authors used the 
Mentimeter programme and 2) an open-ended questionnaire. An open-ended questionnaire is a useful tool for gathering participants' opinions but only when the participants are willing to engage. Most of the time, not all but just some participants would explain what they thought and felt about the learning materials. While they may have had some mental ideas but they might not express these for many reasons; for example, they might not want to spend time writing or typing their opinions. To avoid this issue, the authors used the Mentimeter as another tool for gathering participants' opinions. In the Mentimeter programme, the participants were asked to give three words in Thai that summed up what they thought about the data-driven hospitality lexis learning programme. The reason the authors assigned the participants to express their opinions in Thai was because the participants could express what they exactly thought and using English words to express their opinions might have been a language burden for them that restricted their proper expression. A rating scale questionnaire was avoided in this study because it might not have been effective enough to draw out the participants' opinions. The open-ended questionnaire contained only one question requesting participants to express the advantages, disadvantages, and improvement suggestions of the data-driven hospitality lexis learning programme.

\section{DATA ANALYSIS}

After the authors had classified the participants into the three groups, each group took a pretest relevant to the lesson they had learned. Then, the first group was assigned to use the datadriven tourism lexis learning programme. The second and third groups were assigned to use the data-driven hotel and airline business lexis learning programme, respectively. The participants were free to learn whenever they wanted within a five-week period and they could practice doing exercises as many times as they wished. After five weeks, each participant took a post-test. The means of marks of the three groups in the pre-test and post-test were then calculated using the T-test to evaluate hospitality vocabulary knowledge development by the learners. This study was based on the following null and alternative hypotheses:

$$
\begin{aligned}
& \mathrm{H}_{0}=\mu_{\text {Pre-test }} \geq \mu_{\text {Post-test }}(p=.05) \\
& \mathrm{H}_{1}=\mu_{\text {Pre-test }}<\mu_{\text {Post-test }}(p=.05)
\end{aligned}
$$

The Mentimeter programme and the open-ended questionnaire inspecting learners' opinions were considered and discussed. The information from both kinds of survey could be used to improve the data-driven hospitality lexis learning programme.

\section{FINDINGS}

\section{HOSPITALITY VOCABULARY KNOWLEDGE DEVELOPMENT OF LEARNERS}

The participants were asked to take a pre-test before using the learning programme developed. Then, after five weeks of learning via the data-driven hospitality lexis learning programme, the participants were asked to take a post-test. Figure 4 indicates the average scores for the pre-test and post-test among the three business groups. 


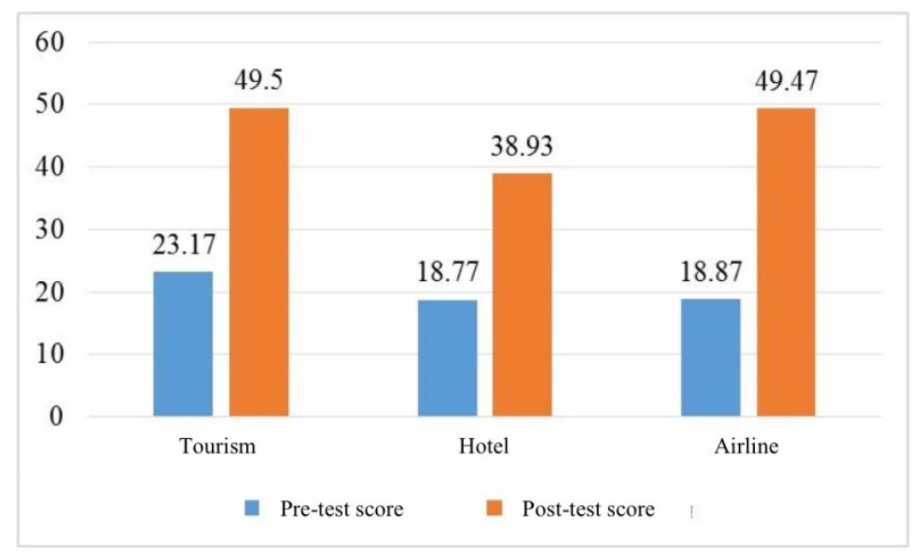

FIGURE 4. Comparison of average pre-test and post-test scores

To analyse the development of learners' vocabulary knowledge, we applied the T-test statistic by comparing the pre-test score with the post-test score at a test level of significance of $p<.05$. The results are indicated in Table 3 .

TABLE 3. Results of pre-test and post-test using the data-driven hospitality lexis learning programme

\begin{tabular}{cccccccc}
\hline \multirow{2}{*}{ Business } & \multirow{2}{*}{ Full marks } & \multicolumn{2}{c}{ Pre-test } & \multicolumn{2}{c}{ Post-test } & \multirow{2}{*}{ t } & \multirow{2}{*}{$\boldsymbol{p}$} \\
\cline { 2 - 6 } & & Mean & S.D. & Mean & S.D. & & .000 \\
Tourism & 60 & 23.17 & 7.28 & 49.50 & 3.83 & -16.38 & .000 \\
Hotel & 60 & 18.77 & 5.03 & 38.93 & 6.74 & -13.75 & .000 \\
Airline & 60 & 18.87 & 5.23 & 49.47 & 3.30 & -35.76 & \\
\hline
\end{tabular}

$p<.05$ considered significant

The results indicated that the post-test mean scores for all groups were significantly higher. The tourism group score was higher by 26.33. Similarly, the hotel group and the airline group scores were also higher by 20.16 and 30.60, respectively. This suggested that the datadriven hospitality lexis learning programme helped participants in learning the vocabulary used in the tourism, hotel and airline businesses. The findings corroborated with previous studies claiming that using DDL could enhance vocabulary teaching and learning (Çelik, 2011; Dörnyei \& Skehan, 2003; Frankenberg-Garcia, 2012; Kaur, 2013; Lin \& Lee, 2015; Soruç \& Tekin, 2017).

\section{OPINIONS ON THE DATA-DRIVEN HOSPITALITY LEXIS LEARNING PROGRAMME}

Two kinds of inspection were used in this study, namely the Mentimeter programme and the open-ended questionnaire. The results were as follows.

\section{MENTIMETER INSPECTION}

The Mentimeter programme is often used to survey opinion and to identify popular answers. In addition, it was used in pedagogy for the purpose of enhancing learners' engagement (Mayhew, 2019; Moorhouse \& Kohnke, 2020; Rudolph, 2018; Vallely \& Gibson, 2018). In the present study, the participants were asked to give three words that they thought described the data-driven hospitality lexis learning programme. Words or phrases most frequently expressed are located in the centre of the diagram (Figure 5) and other words are dispersed depending on their frequency as mentioned by the participants. Since some participants had low English proficiency, all participants were asked to give three words in Thai to avoid a language burden. However, English was also acceptable. 


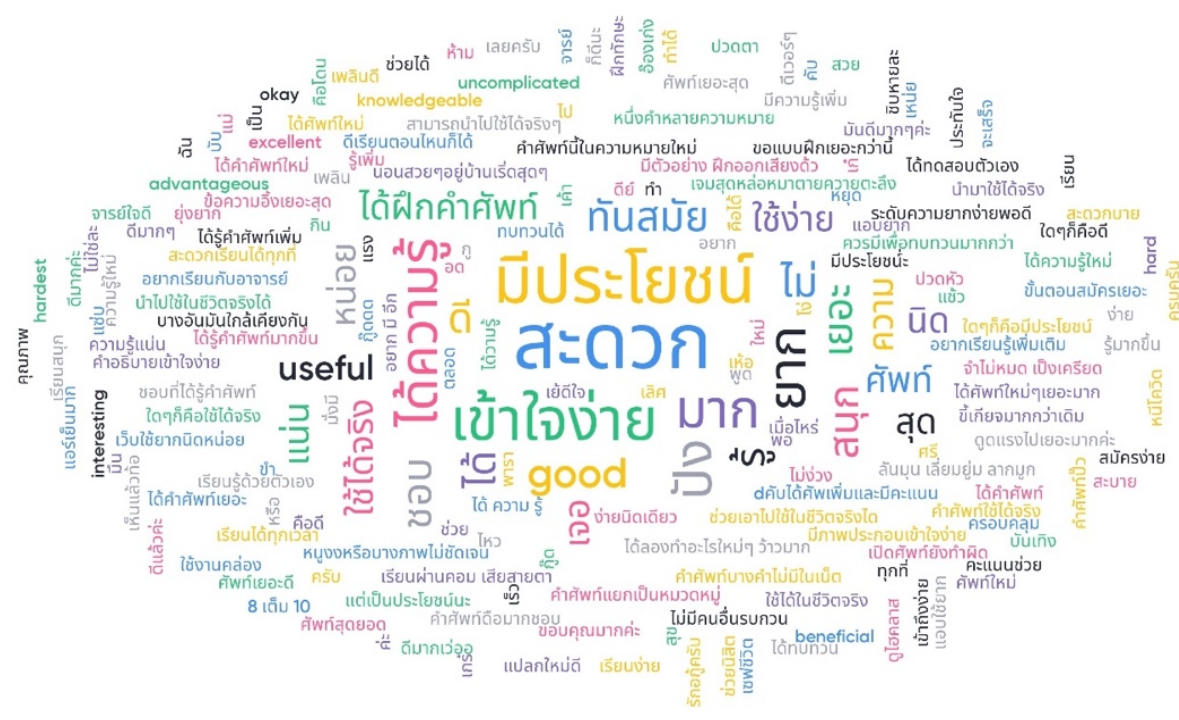

FIGURE 5. Participants' opinion towards the data-driven hospitality lexis learning programme using the Mentimeter programme

The most widely expressed opinion is shown by the largest word in Figure 5 which was "convenient" (สะดวก). Convenience is one of the obvious properties of an online learning programme since the participants can use it anywhere and at any time. Other common words were "useful" (มีประโยชน์) and "easily understood" (เข้าใจง่าย), indicating that the participants viewed the programme as a useful tool for learning vocabulary, and that it was also easily understood which was good for the learning process. Other common opinions were "acquire more knowledge" (ได้ความรู้) and "difficult" (ยาก). This reflected that learning through the programme facilitated learners to acquire vocabulary knowledge. Nevertheless, some participants considered the programme difficult. This was in contrast to other participants who perceived the programme as easy, with such differences due to their different English background knowledge and levels.

\section{OPEN-ENDED QUESTIONNAIRE}

Apart from using the Mentimeter approach, an open-ended questionnaire was also used in this study. The participants were asked to express the advantages and disadvantages, or any improvement required in using the data-driven hospitality lexis learning programme. The acquired comments were then grouped into similar opinions to help identify the trends in the participants' opinions. The results from the open-ended questionnaire supported the results acquired from the Mentimeter programme. The opinions from the open-ended questionnaire could be categorized into four aspects: knowledge acquirement, learning method, learning media, and convenience. Most of the participants confirmed that using the programme increased their tourism, hotel, and airline business vocabulary. They added that learning online was convenient, easily understood, had no pressure, and was freely accessible anywhere at any time. Even though the programme was convenient, there were some restrictions. Using electronic devices such as a computer, laptop, or smartphone requires electricity or a battery and internet access. To solve this issue, the participants suggested providing a "print out function" for users. The participants mentioned that some functions in the programme were unstable and needed to be fixed. In addition, they would have preferred the programme to be more user-friendly. Furthermore, the participants still required instruction from their teachers, and they recommended uploading some video clips explaining some complex vocabulary. An alternative design, such as using Artificial Intelligence (AI) innovation in the programme was 
also suggested. The authors suggested using AI by providing an auto chatbot or animated bot talking to the participants while learning the programme.

\section{DISCUSSION}

Despite the overall increment in the average post-test marks, the hotel business group had a lower increment compared to the other two groups. After announcing the marks to the participants, they were asked to give some feedbacks about the lessons, tests, and their marks. Most of them seemed to have the same feedback for the Mentimeter programme and the openended questionnaire. The participants in the hotel business group additionally informed us that even if their marks had been higher in the pre-test, their average post-test marks would still be lower than the other two groups which might have been because words in the hotel business group were polysemous and that spending five weeks learning these words was inadequate for learners to become familiar with them, especially the low-capability learners. The participants in the tourism and airline business groups agreed with the statement and informed that even though many of the words had never been seen by the learners before, they were more easily memorized since their specific meanings suited the specific contexts, for example, they had never heard of the words 'lavatory' or 'galley' but after learning via the online programme, they never confused using the words. As a result, the participants in the hotel business group seemed to have more issues when taking the test.

Considering the average scores of all participants, the authors believe that successful acquisition of learners' vocabulary knowledge using the online programme autonomously was not as high as expected. There were four possible reasons. First, in the autonomous learning, learners were required to motivate themselves, be responsible, and be good at time management (Benson \& Voller, 1997; Holec, 1981; Waite, 1994). Without committing oneself to learn, one would never acquire knowledge as expected because the success of their lexical growth lies in learners' hand (Kaur, 2013). The marks then reflected their performances. Second, it was very important to give the learners as much time as they wanted to learn through the online material autonomously because learners could achieve their goals with an adequate time provision (Bloom et al., 1981). Hence, spending five weeks on the data-driven hospitality lexis learning programme might be adequate for learners with high English proficiency, but not for those who have low to medium English proficiency. The authors suggest giving the low English proficiency learners more time (longer than five weeks) for these lessons as an appropriate alternative in the future, so they could spend time learning and endeavouring to grasp the lessons. Third, when the participants encountered an unclear situation (such as how to correctly use some words like cuisine and culinary) or when they were confused with some words (such as premier and premium), they required some clear instructions. Nonetheless, the channels to access the teacher to consult on such doubts were inadequate and most learners avoided meeting the teacher face-to-face or having verbal discussion via other means. Zaidieh (2012) confirmed this by emphasizing that the channels for facilitating the communication between teachers and learners were mostly insufficient when learners studied through lessons integrated with social media or online information technology. Therefore, interactive channels between learners and teachers should be provided to enhance the learning process. Finally, the data-driven hospitality lexis learning programme provided figures (both real images and cartoons) for the amusement of the learners. The figures themselves were used as hints that guided learners to the correct answers when doing the practice exercises. This was distinct from the tests that provided only sentences with a blank and five choices for each item. This might be another reason why learners achieved lower marks in the post-test compared with the exercises. 
Even though the overall participants' scores were not as high as expected, the programme still contributed to the learners' vocabulary knowledge improvement. According to the Mentimeter findings, one of the factors affecting vocabulary knowledge improvement was that the programme was proposed in an online version. The data-driven hospitality lexis learning programme is a development of the internet. Therefore, the programme itself suits the "Internet Generation" or so-called Net-Gens, who rely heavily on the internet (Tapscott, 2009). The Net-Gens mostly spend their lives in the virtual community, texting, chatting, and sharing information such as photos and videos every day (Terrell, 2005). Learning online has increased slowly but steadily. In 2002, there were approximately 1.6 million people accessing online learning, while by 2008 , it had reached approximately 4.36 million people (Elaine $\&$ Seaman, 2010). Learning online is generally becoming more common and is seen throughout the world, especially in institutions of higher learning (Omar et al., 2018; Robert et al., 2006). In an online learning process, learners can self-evaluate by considering their marks from exercises. This can help them to decide whether they should re-study and practice doing more exercises or advance to the next activity. Various scholars confirmed that learners could realize and recognize their mistakes from the score shown immediately after finishing the exercises and they liked to measure their progress by taking regular tests (Darasawang \& Reinders, 2010; Nelson et al., 1976).

Despite the development of the internet and the increasing frequency of the Net-Gens, one concern was the familiarity and preference of learners to study through old-fashioned learning materials such as printed matter, slides, and visualizers (Wongsothorn et al., 2019). Due to the recent COVID-19 pandemic which spread throughout many countries including Thailand, many announcements were made by the Ministry of Higher Education, Science, Research and Innovation of Thailand. These included that learning with crowded students in a classroom was strictly prohibited from $1^{\text {st }}$ April 2020. This forced Thai teachers to adopt online learning as well as requiring Thai learners to use online learning materials. This may have initiated the biggest learning transformation in Thailand, since all institutes were forced to adopt online learning methods. Thus, from being just one new option, online learning now exists in the education system and is ready to be further developed for education in a new era (in Thailand).

The authors recommend using the programme as supplementary learning material to reinforce learners' vocabulary knowledge. Teachers might start based on tourism, hotel, or airline business vocabulary depending on individual interest. The three sub-fields connect together since their working environments relate to each other. Hence, learning one sub-field would help learners to learn the other two sub-fields more easily. Thus it is recommended to provide such a programme to learners in the field of hospitality and to include interested learners from other fields. For a better learning outcome, applying the online programme into the course as supplementary learning material might strengthen learners' knowledge and prepare them for higher level courses. Also, learners can improve their higher-order thinking skills; for example, time management, organisation, generalisation and inferences, by learning through activities in an online course (Arifani et al., 2020; Chen, 2005).

For instance, the authors recommend assigning learners to study the programme as supplementary learning material concurrently with learning via the English for Tourism course in class, as shown in the example below. 
TABLE 3. Plan for English for Tourism course using the data-driven hospitality lexis learning programme as supplementary learning material

\begin{tabular}{|c|c|c|c|}
\hline Week & In classroom & $\begin{array}{c}\text { Learning using the } \\
\text { programme }\end{array}$ & Assignment/Remark \\
\hline 1 & *Chapter 1 & Unit 1 Activity 1 & Tracking spent time and exercise marks \\
\hline 2 & *Chapter 2 & Unit 1 Activity 2 & Tracking spent time and exercise marks \\
\hline 3 & *Chapter 3 & Unit 1 Activity 3 & Doing assignment I \\
\hline 4 & *Chapter 4 & Unit 2 Activity 1 & Giving learners feedback \\
\hline 5 & *Chapter 5 & Unit 2 Activity 2 & Tracking spent time and exercise marks \\
\hline 6 & *Chapter 6 & Unit 2 Activity 3 & Doing assignment II \\
\hline 7 & *Chapter 7 & Unit 3 Activity 1 & Giving learners feedback \\
\hline 8 & *Chapter 8 & Unit 3 Activity 2 & Surveying opinions towards the program \\
\hline 9 & *Chapter 9 & Unit 3 Activity 3 & doing assignment III \\
\hline 10 & *Chapter 10 & Unit 4 Activity 1 & Giving learners feedback \\
\hline 11 & *Chapter 11 & Unit 4 Activity 2 & Tracking spent time and exercise marks \\
\hline 12 & *Chapter 12 & Unit 4 Activity 3 & Video clip shooting \\
\hline 13 & *Chapter 13 & Unit 5 Activity 1 & Sharing video clips with classmates online \\
\hline 14 & *Chapter 14 & Unit 5 Activity 2 & Survey opinions towards the program \\
\hline 15 & *Chapter 15 & Unit 5 Activity 3 & Discussion of using the program \\
\hline
\end{tabular}

Teachers might assign learners to use the programme, then track them and always ask for feedback. Their feedback and opinions could illuminate their progress and comprehension. Assignments like writing essays or shooting a video clip using learnt vocabulary might be other ways to investigate their vocabulary development substantially.

Even though online learning material might be one of the methods to attract learners to study outside the classroom, the most important part of online learning material is appropriate lesson content (Lee et al., 2011). Therefore, teachers need to acquire the ability to create attractive, remarkable, and digestible lesson content for an online learning programme.

\section{CONCLUSIONS}

The results of the T-test score provided a response to the research question 1 "Does the datadriven hospitality lexis learning programme contribute to learner's vocabulary knowledge development?", since it indicated that the average marks of the post-test from three businesses were significantly $(p<.05)$ higher than the pre-test marks, which confirmed $\mathrm{H}_{1}=\mu_{\text {Pre-test }}<$

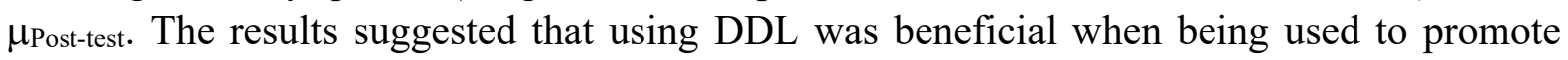
learners' vocabulary knowledge. Since the one group pre-test and post-test design was used as a research design in this study, we might not be able to claim that all the learners' vocabulary knowledge was developed from the implementation of the data-driven hospitality lexis learning programme. Some parts of learners' vocabulary knowledge might have been improved from other uncontrolled factors; for example, some learners might have encountered incidental vocabulary learning when reading texts or listening to someone, or even when watching their favourite movies (Coady, 1993; Krashen, 1989; Webb, 2008). Also, it seemed that the level of students' proficiency had not much influenced their performance levels. In the tourism business group, the three participants with the highest scores from the post-test; all obtaining 55/60, had different pre-test scores of $19 / 60,26 / 60$, and 18/60. The three participants with the first and second lowest post-test scores; 43/60 and 44/60 (two participants obtained 44/60) had pre-test scores of $17 / 60,29 / 60$, and $14 / 60$, respectively. The same results occurred with participants in the hotel and airline business groups. However, the results from the Mentimeter programme and the open-ended questionnaire mentioned that learning through the data-driven hospitality lexis learning programme helped participants to increase the extent of their hospitality 
vocabulary, so this still supported the idea of using the programme as a tool to enhance their vocabulary knowledge.

Two of the most-mentioned expressions regarding the data-driven hospitality lexis learning programme were that the learning outcome was better and that the programme was so convenient. These responses were consistent with Logan (2012) who claimed that learning through electronic devices or computers increased both the success rate of the learning outcome and the satisfaction towards learning. Learner satisfaction in this case suggests that the learners were happy to learn on their own without any external pressure, perhaps because the learners were in their teens which is a time when freedom is most desirable. Visually appealing and appropriate figures were also good tools to encourage learners to spend time using online learning programmes as well as learning online solving of problems with sufficient time available. This corresponded to Bates and Poole (2003) who considered that learning online made asynchronous learning possible so that learners could learn at any time, even without a teacher being present to give instruction. As a result, learners could gain more vocabulary knowledge autonomously. This could be a long-term benefit if learners were trained and familiar with autonomous learning because their lifelong learning skills and learner autonomy would be developed. This would prepare them to be ready for life after graduation (Breen \& Mann, 1997; Dam, 1995; Darasawang \& Reinders, 2010; Littlewood, 1996).

\section{REFERENCES}

Ädel, A. (2010). Using corpora to teach academic writing: Challenges for the direct approach. In M. C. CampoyCubillo, B. Belles-Fortuno, \& M. L. Gea-Valor (Eds.), Corpus-based approaches to ELT (pp. 39-55). London: Continuum.

Allan, R. (2009). Can a graded reader corpus provide 'authentic' input? ELT Journal, 63(1), 23-32.

Altenberg, B., \& Granger, S. (2002). Recent trends in cross-linguistic lexical studies. In B. Altenberg \& S. Granger (Eds.), Lexis in contrast: Corpus-based approaches (3-48). Amsterdam: John Benjamins.

Anastasiya, N., \& Vira, C. (2018). Can using social media as online Learning platform increase student involvement. In L. Riga (Ed.), Development trends in pedagogical and psychological sciences: the experience of countries of Eastern Europe and prospects of Ukraine (pp. 58-75). Ukraine: Baltija Publishing.

Arifani, Y., Suryanti, S., Wicaksono, B., Inayati, N., \& Setiawan, S. (2020). EFL teacher blended professional training: A review of learners' online and traditional learning interactions quality. $3 L$ : The Southeast Asian Journal of English Language Studies, 26(3), 124-138.

Bank of Thailand. (2017). Thai economic report 2017. Retrieved $1^{\text {st }}$ December 2019 https://www.bot.or.th/Thai/MonetaryPolicy/EconomicConditions/AnnualReport/AnnualReport/Annual Report2560.pdf.

Baskin, S., Iscan, A., Karagoz, B., \& Birol, G. (2017). The use of vocabulary learning strategies in teaching Turkish as a second language. Journal of Education and Practice, 8(9), 126-134.

Bates, A. W., \& Poole, G. (2003). Effective teaching with technology in higher-education. San Francisco: JosseyBass.

Benson, P., \& Voller, P. (1997). Autonomy and independence in language learning. London: Longman.

Bernardini, S. (2000). Systematising serendipity: Proposals for concordancing large corpora with language learners. In L. Burnard, \& T. McEnery (Eds.), Rethinking language pedagogy from a corpus perspective (pp. 225-234). Frankfurt: Peter Lang.

Bill, \& Gates, M. (2010). Next generation learning: The intelligent use of technology to develop innovative learning models and personalized educational pathways. Retrieved from https://www.achievingthedream.org/resource/12697/next-generation-learning-the-intelligent-use-oftechnology-to-develop-innovative-learning-models-and-personalized-educational-pathways.

Bloom, B.S., Madavs, G.F. \& Hastings, J.T. (1981). Evaluation to Improve Learning. New York: Mc Graw- Hill Book.

Bondi, M. (2001). Small corpora and language variation Reflexivity across genres. In M. Ghadessy, A. Henry, \& R. L. Roseberry (Eds.), Small Corpus Studies and ELT: Theory and practice (pp. 135-174). Amsterdam: Benjamins.

Boulton, A. (2011). Data-driven learning: the perpetual enigma. In: S. Goźdź-Roszkowski (ed.), Explorations across languages and corpora (pp. 563-580.). Frankfurt: Peter Lang. 
Boulton, A. (2017). Data-driven learning and language pedagogy. In S. Thorne \& S. May (eds.), Language, Education and Technology: Encyclopedia of Language and Education. Berlín \& Heidelberg: Springer International Publishing, 181-192.

Bransford, J., Brown, A., \& Cocking, R. (1999). How people learn: brain, mind, experience and school. Washington, D.C.: National Academy Press.

Breen, M. \& Mann, S. (1997). Shooting arrows at the sun: Perspectives on pedagogy for autonomy. In P. Benson and P.Voller (Eds.), Autonomy and independence in language learning (pp.132-149). London: Longman.

Catalán, R. M. J. (2003). Sex differences in L2 vocabulary learning strategies. International Journal of Applied Linguistics, 13(1), 54-77.

Çelik, S. (2011). Developing collocational competence through web based concordance activities. NovitasROYAL, 5(2), 273-286.

Chen, B., \& Bryer, T. (2012). Investigating instructional strategies for using social media in formal and informal learning. The International Review of Research in Open and Distance Learning, 13(1), 87-104.

Chen, C. E. (2005). Experience-based language learning through asynchronous discussion. The 22nd International Conference on English Teaching and Learning, $1-21$.

Chumworatayee, T. \& Pitakpong, T. (2017). The relationships between the use of vocabulary learning strategies and their usefulness as perceived by English Major students in a Thai university. Language Education and Acquisition Research Network Journal, 10(2), 155-167.

Coady, J. (1993). Research on ESL/EFL vocabulary acquisition: Putting it in context. In T. Huckin, M. Haynes, \& J. Coady (Eds). Second language reading and vocabulary learning (pp.3-23). Norwood NJ: Ablex Publishing.

Conrad, S. (2000). Will corpus linguistics revolutionize grammar teaching in the 21 st century? Tesol Quarterly, $34(3), 548-560$.

Cotos, E. (2014). Enhancing writing pedagogy with learner corpus data. ReCALL, 26(2), 202-224.

Dam, L. (1995). Learner autonomy 3: From theory to classroom practice. Dublin: Authentik.

Darasawang, P., \& Reinders, H. (2010). Encouraging autonomy with an online language support system. $C A L L-$ EJ Online, 11(2), 1-9.

Dörnyei, Z., \& Skehan, P. (2003). Individual differences in second language learning. In C. Doughty \& M. Long (Eds.), Handbook of second language acquisition (pp. 589-630). Oxford, UK: Blackwell.

Elaine, A., \& Seaman, J. (2010). Learning on demand: Online education in the United States, 2009. United States of America: Babson Survey Research Group.

Flowerdew, L. (2005). An integration of corpus-based and genre-based approaches to text analysis in EAP/ESP: countering claims against corpus-based methodologies. English for Specific Purposes, 24(3), 321-332.

Frankenberg-Garcia, A. (2012). Learners' use of corpus examples. International Journal of Lexicography, 25(3), 273-296.

Fung, A. (1999). Consultancy study for the conduct of a value for money audit on the School Administration and Management System and information technology in education. Retrieved from the Audit Commission of the Hong Kong SAR Government

Fung, A., \& Pun, S. W. (2001). ICT in Hong Kong education. Journal of Southeast Asian Ministers of Education, 2(1), 165-180.

Gavioli, L. (2009). Corpus analysis and the achievement of learner autonomy in interaction. In L. Lombardo (Ed.), Using corpora to learn about language and discourse (pp. 39-71). Bern, Switzerland: Peter Lang

Geluso, J., \& Yamaguchi, A. (2014). Discovering formulaic language through data-driven learning: Student attitudes and efficacy. ReCALL, 26(2), 225-242.

Gilquin, G. \& Granger, C. (2010). How can data-driven learning be used in language teaching? In: A. O'Keeffe \& M. McCarthy (eds.), Routledge handbook of corpus linguistics (pp. 359-370). London: Routledge.

Goldman, S. (2011). Technology for teaching and learning with understanding. In J. Cooper (Ed.), Classroom teaching skills (pp. 185-234). Boston: Houghton Mifflin.

Hajhashemi, K., Anderson, N., Jackson, C., \& Caltabiano, N. (2014). Online learning: increasing learning opportunities. Paper presented at the INTCESS14- International Conference on Education and Social Sciences, Istanbul, Turkey.

Henry, L. A., Coiro, J., \& Castek, J. (2005). The flickering mind: The false promise of technology in the classroom and how learning can be saved. Journal of Adolescent \& Adult Literacy, 48(5), 442-445.

Holec, H. (1981). Autonomy in foreign language learning. Oxford: Pergamon.

Huang, L. S. (2011). Corpus-aided language learning. ELT journal, 65(4), 1-4.

Huang, Z. (2014). The effects of paper-based DDL on the acquisition of lexicogrammatical patterns in L2 writing. ReCALL, 26(2), 163-183.

Islam, N., Beer, M. \& Slack, F. (2015). E-Learning Challenges Faced by Academics in Higher Education: A Literature Review. Journal of Education and Training Studies, 3(5): 102-112.

Johns, T. (1986). Micro-concord: a language learner's research tool. System, 14(2), 151-162 
Johns, T. (1991). Should you be persuaded.: Two samples of data-driven learning materials. Classroom Concordancing: ELR Journal. 4, 1-16.

Johns, T. (1994). From printout to handout: Grammar and vocabulary teaching in the context of data-driven learning. In T. Odlin (Ed.), Perspectives on Pedagogical Grammar (Cambridge Applied Linguistics, pp. 293-313). Cambridge: Cambridge University Press.

Kaur, N. (2013). The need for autonomous vocabulary learners in the Malaysian ESL classroom. Journal of Language Studies, 13(3), 101-112.

Kaya, J. (2014). Vocabulary learning strategies: A study of Congolese English language learners. (Master's thesis). Southern Illinois University Carbondale.

Khan, S. (2012). The one world schoolhouse: Education reimagined. London, England: Hodder and Stoughton.

Kilıçkaya, F. (2015). Computer-based grammar instruction in an EFL context: Improving the effectiveness of teaching adverbial clauses. Computer Assisted Language Learning, 28(4), 325-340.

Kilimci, A. (2017). Learner Perspectives towards corpus use in vocabulary learning. International Journal of Language Academy, 5(6), 343-359.

Kırkgöz, Y. (2006). Designing a corpus based English reading course for academic purposes. Reading, 6(3), 281298.

Kong, S. C., Au, W. K., \& Pun, S. W. (1999). A case study on the implementation of information technology education pilot scheme in Hong Kong. In G. Cumming, T. Okamoto, \& L. Gomez (Eds.), Advanced research in computers and communications in education (Vol. 2, pp. 27-34). Netherlands: IOS Press.

Krashen, S. D. (1989). We acquire vocabulary and spelling by reading: Additional evidence for the input hypothesis. The Modern Language Journal, 73, 440-464.

Laosrirattanachai, P., and Ruangjaroon, S. (2021). Corpus-based Creation of Tourism, Hotel, and Airline Business Word Lists. LEARN Journal: Language Education and Acquisition Research Network, 14(1), 50-86.

Laufer, B., \& Nation, P. (1995). Vocabulary size and use: Lexical richness in L2 written production. Applied Linguistics, 16(3), 307-332.

Laufer, B. (2005). Instructed second language vocabulary learning: The fault in the "default hypothesis". In A. Housen \& M. Pierrard (Eds.), Investigations in Instructed SLA (pp. 311-329). Berlin/NY: Mouton de Gruyter.

Law, N., Yuen, H. K., Ki, W. W., Li, S. C., \& Lee, Y. (1999). The second international information technology in education study Hong Kong SAR report. Hong Kong: CITE Centre, University of Hong Kong

Lee, S. J., Srinivasan, S., Trail, T., Lewis, D., \& Lopez, S. (2011). Internet and Higher Education Examining the relationship among student perception of support, course satisfaction, and learning outcomes in online learning. The Internet and Higher Education, 14(3), 158-163.

Lego Muñoz, C., \& Towner, T. (2009). Opening Facebook: How to use Facebook in the college classroom. Paper presented at the Society for Information Technology \& Teacher Education International Conference, Chesapeake, VA.

Lestari, I. W., \& Hardiyanti, N. (2020). Vocabulary learning autonomy through incorporation of English songs: Indonesian EFL students' perspectives. 3L: The Southeast Asian Journal of English Language Studies, 26(2), 91-104.

Lin, M. H., \& Lee, J. (2015). Data-driven learning: Changing the teaching of grammar in EFL classes. ELT Journal, 69(3), 264-274.

Littlewood, W. (1996). Autonomy: An autonomy and a framework. System, 24(4), 427-435.

Liu, D., \& Jiang, P. (2009). Using a corpus-based lexicogrammatical approach to grammar instruction in EFL and ESL contexts. Modern Language Journal, 93(1), 61-78.

Logan, R. (2012). Using YouTube in perioperative nursing education. . AORN Journal, 95(4), 474-481.

MacArthur, F., \& Littlemore, J. (2008). A discovery approach to figurative language learning with the use of corpora. In F. Boers \& S. Lindstromberg (Eds.), Cognitive Linguistic Approaches to Teaching Vocabulary and Phraseology (pp. 159-88). Berlin; New York: Mouton de Gruyter.

Mayhew, E. (2019). No Longer a Silent Partner: How Mentimeter can enhance teaching and learning within Political Science. Journal of Political Science Education, 15(4), 546-551.

McCarten, Jeanne. (2007). Teaching Vocabulary: Lessons from the Corpus, Lessons for the Classroom. Cambridge: Cambridge University Press.

McCoog, I. (2007). Integrated instruction: Multiple intelligences and technology. The Clearing House, 81(1), 2528.

McInnis, C. (2002). The impact of technology on faculty performance and its evaluation. New Directions for Institutional Research, 114, 53-61.

Mirzaii, M. (2012). Implicit vs explicit vocabulary learning: Which approach serves long-term recall better? The Southeast Asian Journal of English Language Studies, 18(2), 1-12.

Moorhouse, B., \& Kohnke, L. (2020). Using Mentimeter to elicit student responses in the EAP/ESP classroom. RELC Journal, 51(1), 198-204. 
Nation. P. (1990). Teaching and learning vocabulary. New York: Newbury House.

National Statistical Office. (2013). The census of business and industry 2012: Trading and service businesses Thailand Kingdom $\quad$ issue. $\quad$ Retrieved $\quad 1^{\text {st }} \quad$ December 2019 http://www.nso.go.th/sites/2014/2555/ข้อมูลเบื้องต้นข้อมูลรายละเอียดการแจกแจงนับ/การค้าการบริการ/ทั่วราชอาณาจักร/det_whol e.pdf.

National Statistical Office. (2016). The survey of information technology usage and communication in household 2016. Ministry of Digital Economy and Society.

Nelson, G. E., Ward, J. R., Desch, S. H., \& Kaplow, R. (1976). Two new strategies for computer assisted language instruction. Computer Journal of Foreign Language Annals, 9(2), 28-37.

Norazah, N., Halimah, Z., \& Rosseni, D. (2005). Integrating pedagogy and instructional design in the e-learning approach for the teaching of mathematics. Paper presented at the Second International Conference on ELearning for Knowledge-Based Society.

Nguyen, L. T. C., \& Nation, P. (2011). A bilingual vocabulary size test of English for Vietnamese learners. RELC Journal, 42(1), 86-99.

Office of the Higher Education Commission. (2018). The verified programs from the office of the Higher Education Commission between 2012-2018. Retrieved $1^{\text {st }}$ December 2019 http://www.mua.go.th/users/bhes/MUA_CURR/CurrCer.html.

Omar, A., Amir, Z., \& Mohamad, M. (2018). Facilitating online learning: Students' online discussion strategies for a project work at a technical university in Malaysia. 3L: The Southeast Asian Journal of English Language Studies, 26(3), 124-138.

Oxford, R. L. (1990). Language learning strategies: What every teacher should know. New York: Newbury House. Pacansky-Brock, M. (2013). Best practices for teaching with emerging technologies. New York, NY: Routledge.

Petrovic, N., Petrovic, D., \& Jeremic, V. (2012). Possible educational use of Facebook in higher environmental education. Paper presented at the ICICTE 2012

Puagsang, N., \& Intharaksa, U. (2017). Vocational students' use of vocabulary learning strategies. PASAA Paritat Journal, 32, 146-165.

Reppen, R. (2010). Using corpora in the language classroom. Cambridge: Cambridge University Press.

Robert, E., Goodyear, P., Prosser, M., \& O'hara, A. (2006). How and what university students learn through online and face-to-face discussion: Conceptions, intentions and approaches. Journal of Computer Assisted Learning, 22(4), 244-256.

Römer, U. (2011). Corpus Research Applications in Second Language Teaching. Annual Review of Applied Linguistics, 31, 205-225.

Rudolph, J. (2018). A brief review of Mentimeter - A student response system. Journal of Applied Learning \& Teaching, 1(1), 35-38.

Schmitt, D. (2008). Summer school 2018 - Assessing vocabulary. [Online lecture] Retrieved from https://www.youtube.com/watch? $\mathrm{v}=\mathrm{IXNc} 5 \mathrm{Nb} 4 \mathrm{bc}$.

Schmitt, N. (1997). Vocabulary learning strategies. In N. Schmitt \& M. McCarthy (Eds.), Vocabulary: Description, acquisition, and pedagogy (pp. 199-227). Cambridge: Cambridge University Press.

Schmitt, N. (2008). Instructed second language vocabulary learning. Language Teaching Research, 12(13), 329363.

Shelly, G., Cashman, T., Gunter, G., \& Gunter, R. (2007). Teachers discovering computer: Integrating technology and digital media in the classroom. Boston, MA: Course Technology.

Smith, S. (2020). DIY corpora for Accounting \& Finance vocabulary learning. English for Specific Purposes, 57(2020), 1-12.

Soruç, A., \& Tekin, B. (2017). Vocabulary learning through data-driven learning in an English as a second language setting. Educational Sciences: Theory \& Practice, 17(6), 1811-1832.

Tahir, M., Albakri, I., Adnan, A., \& Karim, R. (2020). The effects of explicit vocabulary instructions on secondary ESL students' vocabulary learning. 3L: The Southeast Asian Journal of English Language Studies, 26(2), $158-172$.

Tapscott, D. (2009). Grown up digital: How the Net-generation is changing your world. New York: McGraw-Hil.

Teng, F. (2015). Assessing the relationship between vocabulary learning strategy use and vocabulary knowledge. $P A S A A, 49,39-65$.

Terrell, S. (2005). A longitudinal investigation of the effect of information perception and focus on attrition in online learning environments. The Internet and Higher Education, 8(8), 213-219.

Tono, Y. (2003). What corpora can do for language teaching. English Corpus Studies, 10, 249-264

Umesaki, A. (2004) Using a large-scalecorpus in the classroom. Paper Presented at the 24th Japan Association for English Corpus Studies (JAECS) Conference, Tokyo, Japan.

Vallely, K., \& Gibson, P. (2018). Engaging students on their devices with Mentimeter. Compass: Journal of Learning and Teaching, 11(2), 1-6. 
Vo, T. D., \& Jaturapitakkul, N. (2016). The use of vocabulary learning strategies by Thai EFL learners studying Vietnamese as a third language. Language Education and Acquisition Research Network Journal, 9(2), 105-121.

Waite, S. (1994). Low-resourced self-access with EAP in the developing world: the great enabler. ELT Journal 48(3), 233-242.

Webb, S. (2008). The effects of context on incidental vocabulary learning. Reading in a Foreign Language, 20(2), 232-245.

Widdowson, H.G. (1978). Teaching language as communication. Oxford: Oxford University Press.

Wongsothorn, A., Yordchim, S., Thitivesa, D., \& Pongsurapipa, S. (2019). Innovative use of English language teaching as an international language in graduate studies in Thai universities. Language Education and Acquisition Research Network Journal, 12(2), 14-27.

Yoon, H., \& Hirvela, A. (2004). ESL student attitudes toward corpus use in L2 writing. Journal of Second Language Writing, 13(4), 257-283.

Zahar, R., Cobb, T., \& Spada, N. (2001). Acquiring vocabulary through reading: Effects of frequency and contextual richness. The Canadian Modern Language Review, 57(3), 541- 572.

Zaidieh, A. J. Y. (2012). The use of social networking in education: Challenges and opportunities. World of Computer Science and Information Technology Journal, 2(1), 18-21. 